\title{
Determinants of Academic Achievement Among Secondary School Students in Kericho County, Kenya
}

\author{
Sang Kipchirchir Naftali, Dr. Thaddaeus Rugar \\ Department of Education Management, Policy and Curriculum Development, School of Education, Kenyatta University, Kenya
}

\begin{abstract}
The mean score for mocks exams has been reducing for the last three years, therefore study tried to find out if student mocks (CATs) correlate with family background from which student came from. The objectives of this study were to investigate the effects of parental level of education, parental level of income, parental occupation and family size on student's academic achievement. The study found out that family background indeed influence student academic achievement. Correlational research design was applied to analyze the data. Education production function theory was used to guide the study. 1809 form four students were the target population for the study. Simple random and stratified sampling method was employed to achieve the sample. Questionnaire used to collect data was validated by educational experts from Kenyatta University. Reliability of the instrument was obtained through test-retest. Multiple linear regression models were used to analyze the collected data and quantitative data was presented in tables. Frequencies, regression coefficient and Pearson's coefficient correlation was used to present data analyzed. SPSS version 20 was utilized to generate summarized information in tables. Analyzed results showed that parent level of education, parental occupation and parental income express positive relationship with the student academic achievement however the size of the family express negative relationship with student academic achievement. Parents should participate in academic activities of their children and further studies regarding student academic achievement and family background should be done.
\end{abstract}

Key Words: Parental Income, Parental Occupation, Parental Education Level, Family Size and Student, Academic Achievement.

\section{INTRODUCTION}

\section{Background to the Study}

$\mathrm{K}$ enya advocate for good education and training for Vision 2030 since both will improve the economy of the country. United Nation (2010) categorized education as an important tool to be used to realize second goal of millennium. According to these studies good education produces dynamic people with skills.

Parental status has played a vital role in shaping academic achievement of students in the world. Parents motivate their children's academic at their early age. Barrow, (2006) found out that number of years student stay in education institution and academic achievements was determined by parental background. Looking into the influence of family background on student academic achievement in secondary schools was necessary because education play a major role in developing the nation both socially and economically, (Barrow, 2006) children from stable families achieved better in academic than those from poor families. This was because parents gave school identity by sending their children to school. Thus their influence was felt in school through student academic performance. Student academic achievement defined as the performance of the students in the subject they study in the school (Clark, 2006). Academic achievement places learner to a particular status in the class and school. Academic achievement develops learner's talents and prepares them to tackle academic challenges which might face them in future. Family background in this study was narrowed down to level of education of parent, income, family size, occupation among others.

Occupation has been seen as a factor which influences academic performance. Parents take major role in bringing up children in any given society therefore parental influence cannot be overlooked. Adekay, (2002) concluded that children are socialized by their parents to become productive people in future. Memo, (2010) found significant relationship between parent occupation and student academic performance. Student whose fathers work in highly paying occupation do better academically when compared to learners whose fathers work in less paying occupation. Kabinga, (2014) in his research in Tanzania stated that parents from formal occupation were able to assist their children at home and also in school. This occupation has regular payment which gives parents ability to provide their children academic necessities like reading and writing materials. On the other hand informal occupation such as peasantry and carpentry rope parents ability to prove academic necessities to their children.

Parents with university education encourage their children to learn more than parents with less education, (Becker, 2011) also asserts that a parents' academic interaction propels the ways the learner perform the exams by influencing of his/her behavior relating to school Becker, (2011) also found out that parental involvement in education increases educational effectiveness of the time that the parents and their children spend together. The teachers, parents and the administrators of 
various secondary schools have established schemes of operations where there is an arrangement to encourage the trio. The studies never talked about the parents who are not educated.

Fathers education influence both boys and girls while mother's education influence only girls, (Chen, 2009) in his studies in China found out though both parents education pose influence to children math performance, their influence differ. Kamau, (2013) state in his studies that parental education influence child's achievement in school.

Children from large families have greater do well in academic since they is competition among themselves and older children help younger to learn, (Osuafor, 2013) on the other hand state in his studies that children from large families achieve higher than those from small families this is because grownup children teach small children. Also parents encourage their children to compete for present through their academic performance. Kamau, (2013) states in her research that families with many dependents have no influence on student academic performance. These studies did not have common conclusion thus creating a gap which this study sought to fill.

Kipkelion East Sub-County had been performing poorly has evidence by the reducing mean of mocks. The mean was 5.52 in the year 2014 and a drop to 4.5 in the year 2015 and 4.13 in 2016. This is the negative trend which is against the expectation of education stakeholders. Investigating how family background is related to student academic achievement in Kipkelion East Sub-County was important since research that have been done shows that despite the fact that student are being taken to the same school, differ in academic achievement. It is important to note that issues regarding family background and student academic achievement in Kipkelion East Sub-County have not been studied hence the study investigated the influence of student family background on their academic performance. Family background was looked at in relation to parent type of occupation, size, level of income and level of education.

\section{Statement of the Problem}

Poor academic achievement among students has been of great concern to educationists and government. Despite huge resources allocated to education by the Kenyan government which is used to cater for free secondary education, hiring of teachers, feeding programs still students achieve less than expectation in academics performance in Kipkelion East SubCounty. In Kipkelion East Sub-County, the mean score of mocks was 5.52 in the year 2014 and a drop to 4.5 in the year 2015 and 4.13 in 2016 (Mocks Analysis, 2016). Mocks exam are very vital in predicting the KCSE achievement (Oketch, 2004). Hence this background shows that Kipkelion East Sub-County schools achieve less than average which created the need to investigate if family background had contributed to such dismal in academic achievement of secondary students in the sub county. Studies which had been done showed that family background is related to academic achievement. Others have denied the same. The researcher has made efforts to find out if there is any literature that gives in depth information about influence of family background specifically family size, parental education, parental occupation and parental income on student academic achievement in Kipkelion East SubCounty, according to his knowledge he has not come across any studies that have been done on influence of family background specifically family size, parental education, parental occupation and parental income on student academic achievement in Kipkelion East Sub-County. Therefore, it became necessary to find out how family background influenced student's academic achievement in Kipkelion East Sub-County.

\section{Objectives of the Study}

The objectives of this study were to:

i) Determine the relationship between parental level of education and student academic achievement among students in secondary schools in Kipkelion East Sub County.

ii) Establish the relationship between family size and student academic achievement in Kipkelion East Sub-County

iii) Investigate the relationship between parental occupation and student's academic achievement in secondary schools in Kipkelion East Sub-county.

iv) Establish relationship between parental level of income and student academic achievement in secondary schools in Kipkelion East Sub-county.

\section{Significance of the Study}

Study is significant because it increased the bank of knowledge which exists on the influence of parental background on student's academic achievement. Studies on the causes of poor academic achievement in Kipkelion East Sub-County based on the family background is significant to the Kenyan government since the government of Kenya will utilized the information on the findings to solve problems relating to student academic achievement and family background. Kenyan policy makers also benefited with the findings since it helped them to realign the policies regarding student academic achievement. Teachers and principals can utilize the report in correcting poor academic achievement caused by family background.

\section{Theoretical Framework}

A theory is a coherent group of tested general proposition, commonly regarded as correct that can be used as principle of explanation and prediction for a class of phenomenon according to Oxford dictionary. This study was based on (Hanushek, 1992) theory of Education Production Function (EPF) which place the emphasis on the minimum input requirements needed to produce designated quantities of 
output. Education production function is the application of the economic concept of production function to the field of education.

Education Production Function relates various inputs affecting the student's learning to measured outputs. These inputs include family background which include; (parent height of schooling, income of parent, type of job parent do and, number of people depending on family). The output is the student's academic achievement which is measured in child Cats results.

Family background which include; (parental level of education, parental level of income, parental occupation, family size) were the inputs. Student individual scores were regarded as outputs

Conceptual Framework

\section{Inputs}

\section{Independent Variables}

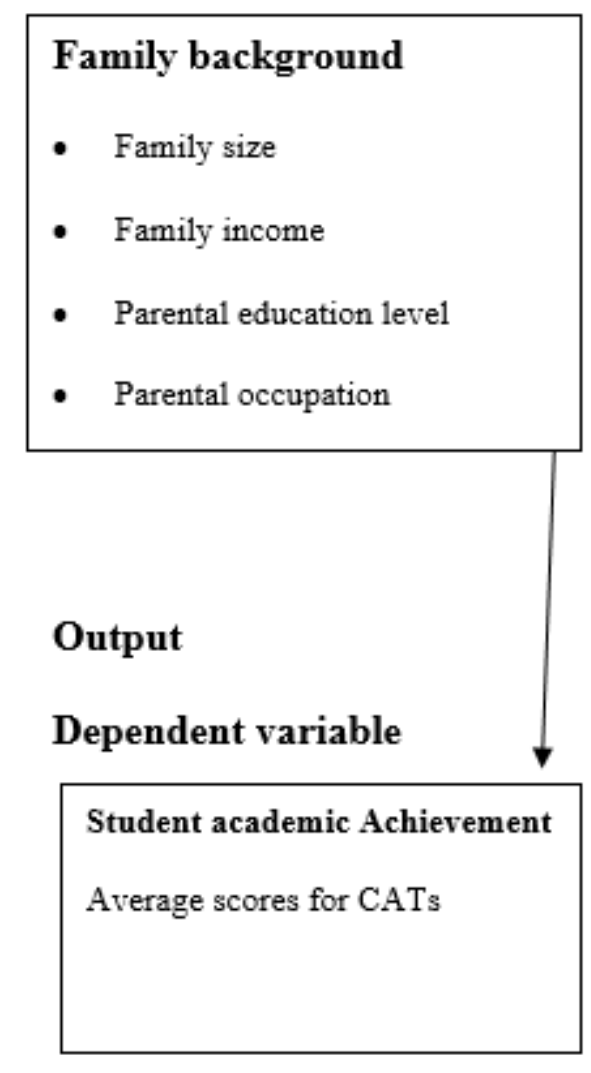

Figure 1.1: Conceptual Framework

The following were the independent variables; Family background, which were regarded as inputs. It had been broken down as follows: family size, parental income, and parental level of educational and parental occupation. Student academic achievement was the dependent variable and regarded as the output.

\section{LITERATURE REVIEW}

Many researchers have found out conflicting results in different part of the world concerning relationship between family background and student academic achievement. Some found family background to be positively related with student academic achievement while some found negative relationship. Francis, (2015) found out that learners who experience problem in paying school levies were also irregular in school which in turn reduce their academic achievement. Murithi, (2015) stated that parents who are economically buoyance involve themselves in school activities hence being in a position to help their children academically than poor parents who occupy all their time in looking for food. Ndege, (2010), Ayal, (2014), state that the size of the family influence academic achievement of the student. Kamau, (2013) found no relationship between large families and student academic performance. Murithi, (2015), Mattison, (2014), Mwaniki, (2013), concluded that parent with high education influence their children's academic performance more than parents with low education. Osuafor, (2013) state that students who are their parents are civil servants outperform academically students who's their parents engage in business. Epstein, (2012) contradict Osuafor, (2013). When he noted that a police have no time for checking academic progress of their children on a daily basis while teachers and farmers have a lot of time. Osuafor, (2013) concluded that parental occupation is not related with student performance in biology. Most studies have shown that parents play a major role in improving their children/students' academic achievement. Stages in education are determined by examination thus students who passed exams are allowed to move to the next stage while those who fail are seen as failures (Kombo, 1988). Students therefore are required to achieve higher grades in exams. Family background and its relationship with student academic achievement in Kipkelion east sub-county Kericho, Kenya was investigated in this study.

\section{RESEARCH DESIGN AND METHODOLOGY}

\section{Research Design}

Research design is a blue print for the collection, measurement and analyzing of data (Kothari, 2003). This study adopted correlational research design to investigate the relationship between family background and academic achievement of secondary school students in Kipkelion East Sub-County. This research design enabled the researcher to describe and measure the degree of relationship among variables being investigated without manipulating them. Correlation research design was appropriate for the study as it allowed describing, recording, analyzing and reporting the relationship which exist among variables. Correlation research deals with variables which interact with each other in that when one changes it gives the direction of change to the other. According to Creswell, (2012) correlational research studies are designed to describe and measure the degree of relation 
between two or more variables without manipulating any variable hence the choice of the design. The research was done in Kipkelion East Sub-County in Kericho County, Kenya.

Table 3.1: Variables Definition and Measurement

\begin{tabular}{|c|c|c|}
\hline Variable & Type & Measurement \\
\hline $\begin{array}{c}\text { Student academic } \\
\text { achievement }\end{array}$ & Dependent & CATs scores \\
\hline Parental level of education & Independent & Years of schooling \\
\hline Family size & Independent & $\begin{array}{c}\text { Number of people in a } \\
\text { household }\end{array}$ \\
\hline Parental occupation & Independent & $\begin{array}{c}\text { Source of income e.g. } \\
\text { Employment, Business, and } \\
\text { Farming. }\end{array}$ \\
\hline Parental income & Independent & $\begin{array}{c}\text { Approximate money earned } \\
\text { in one year in Kenya } \\
\text { shillings }\end{array}$ \\
\hline
\end{tabular}

\section{Location of the Study}

The study was conducted in Kipkelion East Sub-County in Kericho -County.

Kipkelion east has 32 public and private secondary schools which is considered to provide good sizeable sample to be used in the study compared to Kipkelion west which has only 20 public and private secondary schools. The parents from west of Kipkelion east grows coffee while those from east grows maize this brought variation in household which creates relevancy to the proposed study. Over the last three years Kipkelion East Sub-County have been posting poor results in mocks in 2014 the mean score of KCSE was 5.52 it drop to 4.5 and 4.13 in 2015 and 2016 respectively. This necessitated the inquiry to whether family background is contributing to such poor results.

\section{Target Population}

It is taken as a full set of cases from which a sample is taken (Saunders, 1997). This study targeted all (32) public and private secondary school and all form four students enrolled in form four 2017 in Kipkelion East Sub-County. The sub county is densely populated with 1809 form four students in secondary school. Sampling Techniques and Sample Size

\section{Sampling Techniques}

Mugenda, and Mugenda, (1999), state that sampling is the process of selecting the subjects or cases to be included in the study as representative of the target population. The study employed simple random technique to select the 10 out 32 schools for study which is $30 \%$ of the target population as advocated by (Mugenda, and Mugenda, 2003) who argued that $30 \%$ of the target population is sufficient to be the representative of entire population. All the 32 schools were given equal chance of selection by assigning numbers ranging from 1-32 then folded mixed in a basin and 10 numbers are picked randomly. Boys and girls were separated using Stratified sampling to ensure equal representation of boys and girls in mixed schools. The sample was separated to homogenous group of boys and girls to ensure equal representation of boys and girls. Therefore the sample of this study were 10 out of 32 public and private secondary schools which was $30 \%$ of the total number of schools. 200 students was arrived at with the help of (Stauffer, \& et al, 2006) formula. Sampling of students in each school was based on simple random sampling procedure using the students CATs scores.

\section{Sample Size}

The sample SIZE is a smaller but hopefully representative unit from a population which is used to determine the truth about that population. This study was determined using the (Stauffer, \& et al, 2006).

Sample size $=$

$$
\frac{n}{1+[n / N]}
$$

Where

$\mathrm{N}=$ target population which is all students enrolled in form four 2017. The number of students is 1809

$$
n=\text { desired sample size } n=z^{2} \frac{[p(1-p)]}{d^{2}}
$$

$\mathrm{p}=$ the expected frequency of the factor under study is $22 \%$ based on (Stauffer, \& et al., 2006)

$\mathrm{z}=1.960$ confidence limit of $95 \%$

$\mathrm{d}=$ normal deviation of 0.05

Therefore:

$\mathrm{n}=1.960^{2}[0.22(1-0.22)]$

$$
0.05^{2}
$$

$$
=263.6874
$$

Sample size $\quad=\quad \underline{263.6874}$

$$
\begin{array}{lc} 
& 1+(263.6874 / 1809) \quad=200 \\
\text { Boys } & 200 * 0.564=112.8 \\
\text { Girls } & \underline{200 * 0.436}=87.2
\end{array}
$$

The table below shows the target population and sample size

Table 3.2: Target Population and Sample size

\begin{tabular}{|c|c|c|}
\hline & $\begin{array}{c}\text { N (target } \\
\text { population) }\end{array}$ & $\begin{array}{c}\text { N (sample } \\
\text { size) }\end{array}$ \\
\hline Boys & 1000 & 113 \\
\hline Girls & 809 & 87 \\
\hline Total & 1809 & 200 \\
\hline
\end{tabular}

Research Instruments

\section{Questionnaire for Students}

This was designed by the researcher to generate information from the students themselves regarding to their family 
background and academic achievement. This includes information on the parental education, family size, parental occupation, and parental income. It also provides information on student academic achievement. It was made to allow the students participate freely and be able to provide information on their family background and academic achievement to the best of their knowledge. The student questionnaire was chosen because it gave student humble time and confidents to answer question posed unlike interview which make student to shy away.

\section{Validity}

The supervisor from the department was relied upon to establish content validity of the research instruments. According to Gay, (1987), content validity is established by expert judgment.

\section{Reliability}

To establish the reliability of the instrument, the researcher used the test-retest technique. The test-retest technique involved administering the same instrument twice to the same group of subjects to establish whether the same results can be obtained with a repeated measure of the same concept, (According to Orodho, 2008), reliability concerns the degree to which the particular measuring procedure gives similar results over a number of repeated trials. The instrument was administered to the respondents in one school. Thereafter the respondents' responses, was scored and correlated using the Pearson moment product correlation coefficient to establish the extent to which the contents of the questionnaire was consistent in eliciting the same responses. According to Orodho, (2008), if a minimum correlation coefficient of 0.7 is achieved then the instrument is considered reliable. Therefore the instrument posted correlation coefficient of a minimum of 0.7 with the help of Pearson moment product correlation coefficient, and was accepted as reliable.

\section{Data Collection Procedures}

After permission was granted, through an official letter, from Kenyatta University graduate school and NACOSTI, and respective head teachers of the schools, the research began after the head teachers consent. Thereafter the data was collected by administering the questionnaires, to individual students in the sampled schools. Thereafter the filled questionnaires were collected by researcher to ensure $100 \%$ of the return of the questionnaires. The questionnaires were coded after collection and its information was keyed in SSPS package for analysis.

\section{Data Analysis}

Data analysis is the processing of data to make meaningful information (Saunders, 2009). The data collected through the use of questionnaires, was coded. The data was then analyzed using descriptive statistics and presented in tables, percentages, frequencies and measures of central tendency. The collected information was used to analyze the relationship between family background and student academic achievement so as the right interpretation is done. Multiple linear regression models were used to describe the relationship between parental level of education, family size, parental occupation, and parental income to student academic achievement. This model was appropriate because it was used to understand weather family background (parental level of education, occupation, income and family size) is related to the student academic achievement and explore the form of their relationship. It also help to understand how the typical value of the dependent variable changes when any one of the independent variable is varied while the other independent variable were held fixed.

\section{ANALYSIS, PRESENTATION AND DISCUSSION}

\section{Parental Level of Education and Academic Achievement}

The first objective of this study was to determine the relationship between parental level of education and student academic achievement among students in secondary schools in Kipkelion East Sub County.

Respondents were asked to indicate the highest level of education of their fathers and mothers. The responses were then summarized and further analyzed and the results are presented in table(s) 4.1, 4.2 and 4.3

Table 4.1: Regression Coefficients for Father's Level of Education

\begin{tabular}{|c|c|c|c|c|c|c|}
\hline \multicolumn{2}{|c|}{ Model } & \multicolumn{2}{|c|}{$\begin{array}{c}\text { Unstandardized } \\
\text { Coefficients }\end{array}$} & $\begin{array}{c}\text { Standard } \\
\text { ized } \\
\text { Coeffici } \\
\text { ents }\end{array}$ & \multirow{2}{*}{$\mathrm{t}$} & \multirow{2}{*}{ Sig. } \\
\cline { 3 - 5 } & $\mathrm{B}$ & $\begin{array}{c}\text { Std. } \\
\text { Error }\end{array}$ & Beta & & \\
\hline \multirow{2}{*}{1} & (Constant) & 7.349 & .662 & & 11.104 & .000 \\
\cline { 2 - 6 } & $\begin{array}{c}\text { Highest level } \\
\text { of education } \\
\text { of father }\end{array}$ & 463 & .199 & 194 & 2.330 & .021 \\
\hline
\end{tabular}

a. Dependent Variable: Average grade scores

The table indicate that the father's education influence academic achievement of their children. This is shown with a significant level of 0.021 . It therefore means that as the level of father's education increases the student academic achievement also increases.

Table 4.2: Regression Coefficients for Mother's Level of Education

\begin{tabular}{|c|c|c|c|c|c|c|}
\hline \multicolumn{2}{|c|}{ Model } & \multicolumn{2}{|c|}{$\begin{array}{c}\text { Unstandardized } \\
\text { Coefficients }\end{array}$} & $\begin{array}{c}\text { Standar } \\
\text { dized } \\
\text { Coeffici } \\
\text { ents }\end{array}$ & \multirow{2}{*}{ t } & \multirow{2}{*}{ Sig. } \\
\cline { 3 - 5 } & B & $\begin{array}{c}\text { Std. } \\
\text { Error }\end{array}$ & Beta & & \\
\hline \multirow{2}{*}{1} & (Constant) & 6.453 & .655 & & $\begin{array}{c}9.85 \\
4\end{array}$ & .000 \\
\cline { 2 - 5 } & $\begin{array}{c}\text { Highest level } \\
\text { of education } \\
\text { of Mother }\end{array}$ & .184 & .187 & .079 & .984 & .037 \\
\hline \multicolumn{7}{|c|}{ a. Dependent Variable: Average grade scores } \\
\hline
\end{tabular}


The table indicate that the mother's education influence academic achievement of their children. This is shown with a significant level of 0.037 . This indicated that level of education of mother had positive influence to student academic achievement.

Table 4.3: Influence of Parents Education Level

\begin{tabular}{|c|c|c|c|c|c|}
\hline \multicolumn{2}{|c|}{} & $\begin{array}{c}\text { Freque } \\
\text { ncy }\end{array}$ & $\begin{array}{c}\text { Perce } \\
\text { nt }\end{array}$ & $\begin{array}{c}\text { Valid } \\
\text { Percent }\end{array}$ & $\begin{array}{c}\text { Cumulativ } \\
\text { e Percent }\end{array}$ \\
\hline \multirow{2}{*}{$\begin{array}{c}\text { Val } \\
\text { id }\end{array}$} & No & 74 & 47.7 & 47.7 & 47.7 \\
\cline { 2 - 6 } & Yes & 81 & 52.3 & 52.3 & 100.0 \\
\cline { 2 - 6 } & Total & 155 & 100.0 & 100.0 & \\
\hline
\end{tabular}

The table shows the summary of the opinion of the respondents on the effects of the level of parental education on their achievement. The table indicate that $81(52.3 \%)$ of respondents agreed that parental level of education influence their academic achievement while $74(47.7 \%)$ don't think that level of parental education affects their academic achievement.

The result agrees with the (Davis, 2005) study which found out that parental level of education affect significantly academic achievement of student. Studies also agrees with (Murithi, 2015)who stated that children whose parents are educated performed better than children whose parents were less educated since educated parents involve themselves more in their children academic activities.

\section{Family Size and Academic Achievement}

The second objective of this study was to establish the relationship between family size and student academic achievement in Kipkelion East Sub-County.

Respondents were asked to indicate the number of children their parents had. The responses were then summarized and further analyzed and the results are presented in table(s) 4.4 and 4.5 .

Table 4.4: Regression Coefficients for Family Size

\begin{tabular}{|c|c|c|c|c|c|c|}
\hline \multicolumn{2}{|c|}{ Model } & \multicolumn{2}{|c|}{$\begin{array}{c}\text { Unstandardized } \\
\text { Coefficients }\end{array}$} & $\begin{array}{c}\text { Standar } \\
\text { dized } \\
\text { Coeffici } \\
\text { ents }\end{array}$ & \multirow{2}{*}{ t } & \multirow{2}{*}{ Sig. } \\
\cline { 2 - 5 } & B & $\begin{array}{c}\text { Std. } \\
\text { Error }\end{array}$ & Beta & & \\
\hline \multirow{2}{*}{1} & (Constant) & 5.808 & .426 & & $\begin{array}{c}13.63 \\
0\end{array}$ & .000 \\
\cline { 2 - 7 } & $\begin{array}{c}\text { Number of } \\
\text { Siblings }\end{array}$ & .004 & .072 & .005 & .062 & .951 \\
\hline
\end{tabular}

a. Dependent Variable: Average grade scores

The result shows that the size of the family does not necessarily affect academic achievement. This is shown by 0.951 which is above the significant level of 0.05 . This therefore shows that, the increase or decrease in the number of dependents in the family, did not influence the student academic achievement.
Table 4.5: Family Size and Effects on Academics

\begin{tabular}{|c|c|c|c|c|c|}
\hline \multicolumn{2}{|c|}{} & $\begin{array}{c}\text { Freque } \\
\text { ncy }\end{array}$ & $\begin{array}{c}\text { Perc } \\
\text { ent }\end{array}$ & $\begin{array}{c}\text { Valid } \\
\text { Percent }\end{array}$ & $\begin{array}{c}\text { Cumulative } \\
\text { Percent }\end{array}$ \\
\hline \multirow{3}{*}{$\begin{array}{c}\text { Va } \\
\text { lid }\end{array}$} & No & 86 & 55.7 & 38.7 & 38.7 \\
\cline { 2 - 6 } & $\begin{array}{c}\text { Ye } \\
\text { s }\end{array}$ & 69 & 44.3 & 61.3 & 100.0 \\
\cline { 2 - 6 } & $\begin{array}{c}\text { To } \\
\text { tal }\end{array}$ & 155 & $\begin{array}{c}100 . \\
0\end{array}$ & 100.0 & \\
\hline
\end{tabular}

The summary of opinions indicates that a big percentage of $55.7 \%$ (86) of respondents said that family size did not affect their academic achievement. Results agrees with (Kamau, 2013) who found no relationship between large families and student academic achievement performance.

\section{Parental Occupation and Academic Achievement}

The third objective of this study was to investigate the relationship between parental occupation and student's academic achievement in secondary schools in Kipkelion East Sub-County.

Respondents were asked to indicate the type of job their parents were engaging in. some respondents said their parents were employed in a formal sector, some said their parents were farmers others said their parents were businesspersons.

The responses were then summarized and further analyzed and the results are presented in table(s) 4.6, 4.7 and 4.8.

Table 4.6: Parent Occupation

\begin{tabular}{|c|c|c|c|c|c|}
\hline \multicolumn{2}{|c|}{} & $\begin{array}{c}\text { Freque } \\
\text { ncy }\end{array}$ & $\begin{array}{c}\text { Perc } \\
\text { ent }\end{array}$ & $\begin{array}{c}\text { Valid } \\
\text { Percent }\end{array}$ & $\begin{array}{c}\text { Cumulative } \\
\text { Percent }\end{array}$ \\
\hline \multirow{4}{*}{$\begin{array}{c}\text { Vali } \\
\text { d }\end{array}$} & $\begin{array}{c}\text { Farmin } \\
\text { g }\end{array}$ & 89 & 57.4 & 57.4 & 57.4 \\
\cline { 2 - 6 } & $\begin{array}{c}\text { Emplo } \\
\text { yed }\end{array}$ & 32 & 20.6 & 20.6 & 78.1 \\
\cline { 2 - 6 } & Busine & 28 & 18.1 & 18.1 & 96.1 \\
\cline { 2 - 6 } & Others & 6 & 3.9 & 3.9 & 100.0 \\
\cline { 2 - 6 } & Total & 155 & $\begin{array}{c}100 . \\
0\end{array}$ & 100.0 & \\
\hline
\end{tabular}

The table indicates that most parents were doing farming as their main occupation. This has been represented by 89 $(57.4 \%)$. Those who were employed in a formal sector were represented by $32(20.6 \%)$ while those in business were represented by $28(18.1 \%)$.

Table 4.7: Regression Coefficients for Parental Occupation

\begin{tabular}{|c|c|c|c|c|c|c|}
\hline \multicolumn{2}{|c|}{ Model } & \multicolumn{2}{|c|}{$\begin{array}{c}\text { Unstandardized } \\
\text { Coefficients }\end{array}$} & $\begin{array}{c}\text { Standar } \\
\text { dized } \\
\text { Coeffici } \\
\text { ents }\end{array}$ & t & Sig. \\
\cline { 3 - 7 } 1 & B & $\begin{array}{c}\text { Std. } \\
\text { Error }\end{array}$ & Beta & \\
\cline { 2 - 7 } & $\begin{array}{c}\text { (Constant) } \\
\text { occupatio } \\
\mathrm{n}\end{array}$ & 6.491 & .365 & & 17.765 & .000 \\
\hline \multicolumn{7}{|c|}{ a. Dependent Variable: Average grade scores } \\
\hline
\end{tabular}


The results indicate that parental occupation affects student academic achievement as it is shown with a significant level of 0.43 . This means that occupation of a parent had positive influence on student academic achievement.

Table 4.8: Effects of Parental Occupation on Student's Academic

\begin{tabular}{|c|c|c|c|c|c|}
\hline \multicolumn{2}{|c|}{} & $\begin{array}{c}\text { Freque } \\
\text { ncy }\end{array}$ & $\begin{array}{c}\text { Perce } \\
\text { nt }\end{array}$ & Valid Percent & $\begin{array}{c}\text { Cumulative } \\
\text { Percent }\end{array}$ \\
\hline \multirow{3}{*}{$\begin{array}{c}\text { Val } \\
\text { id }\end{array}$} & No & 74 & 39.7 & 47.7 & 47.7 \\
\cline { 2 - 6 } & Yes & 81 & 60.3 & 52.3 & 100.0 \\
\cline { 2 - 6 } & $\begin{array}{c}\text { Tot } \\
\text { al }\end{array}$ & 155 & 100.0 & 100.0 & \\
\hline
\end{tabular}

Percentage of $60.3 \%$ (81) of respondents said that indeed parental occupation did affect their academic achievement while $39.7 \%$ (74) think that parental occupation did not affect their academic achievement.

The result agrees with (Memo, 2010) who found significant relationship between parent occupation and student academic achievement. he further argue that student whose parents work in highly paying occupation do better academically when compared to learners whose parents work in less paying occupation. Kabinga, (2014) also state that parents from formal occupation were able to assist their children at home and also in school since such occupation had regular payment which gave parents ability to provide to their children academic necessities like reading and writing materials.

\section{Parental Level of Income and Academic Achievement}

The fourth objective of this study was to establish relationship between parental level of income and student academic achievement in secondary schools in Kipkelion East SubCounty.

Respondents were asked to indicate the approximate amount of income accrued by their parents annually. The responses were then summarized and further analyzed and the results are presented in table(s) 4.9, 5.0, 5.1 and 5.2.

Table 4.9: Regression Coefficients for Farmer's Income

\begin{tabular}{|c|c|c|c|c|c|c|}
\hline \multirow{2}{*}{ Model } & \multicolumn{2}{|c|}{$\begin{array}{c}\text { Unstandardized } \\
\text { Coefficients }\end{array}$} & $\begin{array}{c}\text { Standa } \\
\text { rdized } \\
\text { Coeffic } \\
\text { ients }\end{array}$ & \multirow{2}{*}{ t } & \multirow{2}{*}{ Sig. } \\
\cline { 2 - 7 } & B & $\begin{array}{c}\text { Std. } \\
\text { Error }\end{array}$ & Beta & & \\
\hline \multirow{2}{*}{1} & (Constant) & 5.860 & .252 & & 23.243 & .000 \\
\cline { 2 - 7 } & $\begin{array}{c}\text { Annual income } \\
\text { Farmer }\end{array}$ & 7.874 & .000 & .093 & .866 & .029 \\
\hline \multicolumn{7}{|c|}{ a. Dependent Variable: Average grade scores } \\
\hline
\end{tabular}

The result shows that with a perfect significance of .000 the academic achievement stand at 5.860. But with an increase in significance level by .027 , academic achievement increases by 7.874. It therefore means that an increase in parental income led to a positive increase in student academic achievement.
Table 4.10: Regression Coefficients for Employed

\begin{tabular}{|c|c|c|c|c|c|c|}
\hline & \multirow[t]{2}{*}{ Model } & \multicolumn{2}{|c|}{$\begin{array}{l}\text { Unstandardized } \\
\text { Coefficients }\end{array}$} & \multirow{2}{*}{ 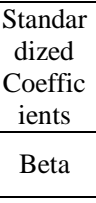 } & \multirow[t]{2}{*}{$\mathrm{t}$} & \multirow[t]{2}{*}{ Sig. } \\
\hline & & B & $\begin{array}{l}\text { Std. } \\
\text { Error }\end{array}$ & & & \\
\hline \multirow[b]{2}{*}{1} & (Constant) & 5.498 & .578 & & 9.507 & .000 \\
\hline & $\begin{array}{l}\text { Annual } \\
\text { Income- } \\
\text { Employed }\end{array}$ & 3.225 & .000 & .287 & 1.643 & .011 \\
\hline \multicolumn{7}{|c|}{ a. Dependent Variable: Average grade scores } \\
\hline
\end{tabular}

Result shows that annual income of employed parents had an influence on academic achievement. This is indicated with a significant level of 0.11 which shows that income influence academic positively.

Table 4.11: Regression Coefficients for Business Parent

\begin{tabular}{|c|c|c|c|c|c|c|}
\hline & \multirow[t]{2}{*}{ Model } & \multicolumn{2}{|c|}{$\begin{array}{c}\text { Unstandardized } \\
\text { Coefficients }\end{array}$} & \multirow{2}{*}{$\begin{array}{c}\text { Stand } \\
\text { ardize } \\
\mathrm{d} \\
\text { Coeffi } \\
\text { cients }\end{array}$} & \multirow[t]{2}{*}{$\mathrm{t}$} & \multirow[t]{2}{*}{ Sig. } \\
\hline & & B & $\begin{array}{c}\text { Std. } \\
\text { Error }\end{array}$ & & & \\
\hline \multirow[b]{2}{*}{1} & (Constant) & 4.339 & .635 & & 6.829 & .000 \\
\hline & $\begin{array}{l}\text { Annual } \\
\text { Income- } \\
\text { business }\end{array}$ & 6.221 & .000 & .334 & 1.807 & .032 \\
\hline
\end{tabular}

Results show significant level of 0.032 . This shows that income affect academic achievement of student.

Table 4.12: Effect of Income on Academic Achievement

\begin{tabular}{|c|c|c|c|c|c|}
\hline \multicolumn{2}{|c|}{} & $\begin{array}{c}\text { Frequen } \\
\text { cy }\end{array}$ & $\begin{array}{c}\text { Perce } \\
\text { nt }\end{array}$ & $\begin{array}{c}\text { Valid } \\
\text { Percent }\end{array}$ & $\begin{array}{c}\text { Cumulative } \\
\text { Percent }\end{array}$ \\
\hline \multirow{3}{*}{$\begin{array}{c}\text { Val } \\
\text { id }\end{array}$} & No & 67 & 43.2 & 43.2 & 43.2 \\
\cline { 2 - 6 } & \begin{tabular}{c} 
Ye \\
\cline { 2 - 6 }
\end{tabular} & 88 & 56.8 & 56.8 & 100.0 \\
\cline { 2 - 6 } & $\begin{array}{c}\text { Tot } \\
\text { al }\end{array}$ & 155 & 100.0 & 100.0 & \\
\hline
\end{tabular}

The table indicates the results of opinion from respondents. $56.8 \%$ (88) of the respondents agreed that parental income affect their academic achievement while $43.2 \%$ (67) said that parental income did not matter in their academic achievement.

The result agrees with (Murithi, 2015) who concluded in his studies that financially able parents participate in academic activities for their children than poor parents. Poor parents don't afford to access community resources which aid student to perform to expected height in academic. Economically able parents provide necessary requirement needed in academic activities to their children making them better in handling exams leading to high academic achievement. Students from rich families enjoy educative gadgets like TV, computers, and charts from their homes while students from poor families are disadvantage this make them to be unprepared for academic activities 


\section{CONCLUSION AND RECOMMENDATION}

\section{Conclusion of the Study}

The findings based on specific objectives were used to study the relationship between independent variables and dependent variables. Conclusion was therefore made using the observation from analyzed data

\section{Parental Level of Education and Academic Achievement}

Basing on the data analyzed the study concluded that parental level of education influence academic achievement. The higher educated parents are the more they participate in academic activities of their children. This in turn influences academic achievement positively.

On the other hand less educated parents don't attract wellpaying jobs which incapacitate them from taking their children to a better school which lead to poor academic performance.

\section{Family Size and Academic Achievement}

Students who came from large families post the same academic achievement with those from smaller families. These studies concluded that family size has no significant influence on student academic achievement.

\section{Parental Occupation and its Influence on Student Academic Achievement}

The study concluded that parental occupation influence academic achievement of student. This is arrived after analyzing the responses from respondents which indicate a significance level of 0.43 . Also over $60 \%$ (81) of respondent agreed that occupation affect their academic achievement while nearly $40 \%$ said that they did not think that occupation influence academic achievement.

\section{Parental Level of Income on Student Academic Achievement}

On the basis of the findings, the study concluded that parental level of income affects significantly student academic achievement.

\section{Recommendation}

The study recommends the following mitigation as per the objectives.

\section{Parental Level of Education and Academic Achievement}

Parents should motivate their children to work hard so as to reach higher level of education.

Basic on the findings, it is recommended that parents should participate in academic activities of their children both at home and school for them to understand the challenge their children go through.

\section{Family Size and Academic Achievement}

Upcoming parents should reduce the number of children to average for them to cater for them adequately.

\section{Parental Occupation and Student Academic Achievement}

Parents should motivate their children to embrace that occupation which are in line with their careers.

\section{Parental Level of Income and Academic Achievement}

The county government of Kericho should train farmers to practice business farming so as to improve economic power of parents. Which in turn improve capability of parents to pay school fees?

\section{Suggestions for Further Research}

Further research should be done on other aspects of family background so as to complete studies pertaining family and student's academic achievement.

\section{REFERENCES}

[1] Adekay, T. (2002, October 3). Friend with Benefits. Retrieved from Google : www.sagepub.com

[2] Ayal, H.A. (2014) Assessment of Factors Affecting Girls Performance in Secondary Schools. Rachuonyo: Retrieved From www.maktaba.ku.ac.ke

[3] Barrow, R. (2006). How family background affects educational attainment: USA. Retrieved from www.maktaba.ku.ac.ke

[4] Becker, H. J (2011). Parent involvement contracts in California's charter schools: Strategy for educational improvement or method of exclusion? Los Alamitos, CA: Southwest Regional Laboratory.

[5] Chen, Q. (2009). Family Background, Ability and Student Achievement. Identifying the Effects of Unobservable Ability. China: University of Minnesota

[6] Clarck, R. (2006). Reconsidering Research on Learning From Media . Retrieved from google : www.jstor.org

[7] Creswell, J.W. (2012) Correlational Research Studies. Retrieved from Kenyatta University:www.maktaba.ku.ac.ke.

[8] Davis, K. (2005). The influence of parent education and family income on child achievement. The indirect role of parental expectation and the home enviroment. family psychology, 19, 294-304.

[9] Francis, N. K. (2015). Influence of Parents Socio-Economic Background On Student Kcse Performance In Public Secondary School In Kibwezi District Makueni County. Retrieved from Kenyatta University :www.maktaba.ku.ac. ke

[10] Gay, L. (1987). Education Research Competence for Analysis and Application, Columbus Ohio, Merill.

[11] Hanushek, E. (1992). Theory of Education Production Function. Retrieved from www.google.com

[12] Kabinga, O. S. (2014). Impact of Parental Social Economic Status of Student Academic Achievement. Retrieved from Kenyatta University: www.maktaba. ku.ac.ke

[13] Kamau, L. M. (2013).Relationship between Family Background and Academic Performance of Secondary Schools Students. Med Thesis Siakago: Retrieved from kenyatta university : www.maktaba.ku.ac.ke

[14] KNEC (2016) KCSE Analysis. Retrieved from www.kneck.ac.ke

[15] Kombo, D. K. (1988). Causes of Poor Performance in Harambee Secondary Schools: Kathiani Division. Retrieved from www.maktaba.ku.ac.ke

[16] Kothari, C. R. (2003). Research Methodology: Methods and Techniques.New Dheli: New Age International.

[17] Mattison, S. M. (2014). parental investment and and the positive effects of fathers among the Matrilineal mosou of south west china. china.

[18] Memo, A. (2010). The Relationship between the Socio Economic Status of Parents and Student Academic Achievement in Social Studies. Retrieved from research in education : www.maktaba.ku.ac.ke 
[19] Mugenda, O. \& Mugenda, A. (2003). Research Methods. Quantitative \&Qualitative Approaches. Nairobi: Acts Press.

[20] Mocks Analysis, (2016). Joint Kipkelion East mocks. Kipkelion.

[21] Mugenda, O. \& Mugenda, A. (1999). Research Methods. Quantitative \& Qualitative Approaches. Nairobi: Acts Press.

[22] Murithi, G. W. (2015). Parental Determinats of Academic Performance of Learners in Public Day Secondary School. Retrieved from Kenyatta University : www.maktaba.ku.ac.ke

[23] Mwaniki, J. M. (2013, december ). Effects of Social Economic and Istitution Factors on Boys Performance in KCSE: Subukia District Kenya . Retrieved from kenyatta university : www.maktaba.ku.ac.ke

[24] Ndege, W. M. (2010). Factors Influencing Academic Performance in Day Secondary School in Essise Divission borabu District . Retrieved from Kenyatta University: www.maktaba.ku.ac.ke

[25] Oketch, C.O. (2004). Relationship between the achievement of form four students in mocks and KCSE examination. Retrieved from www.maktaba.ku.ac.ke
[26] Orodho, J. A. (2008). Techniques of writing resaerch proposal and report in education and social science. Nairobi: kazezja

[27] Osuafor, A. (2013). Influence of Family Background on Academic Achievement of Secondary School Biology Student . Retrieved from kenyatta university: www.maktaba.ku.ac.ke

[28] Saunders, M. (2009). Research methods. $5^{\text {th }}$ edition. London: Prentice Hall.

[29] Saundersm, M. (1997): Research methods for business students. Edinburg: Pearson Education Company.

[30] Stauffer, W. \& Etal (2006) Prevalence and Incidence of Entamoeba Histolytica. South Africa and Egypt. Retrieved from www.maktaba.ku.ac.ke

[31] United Nation (2010) Second Goal of Millennium. Retrieved from www.un.com 